\title{
Structural and Stratigraphical Correlation of Seismic Profiles between Drigri Anticline and Bahawalpur High in Central Indus Basin of Pakistan
}

\author{
Shazia Asim¹, S. N. Qureshi' ${ }^{2}$, Summyia Khatoon Asif ${ }^{3}$, Shabeer Ahmed Abbasi ${ }^{4}$, \\ Sarfraz Solangi ${ }^{5}$, M. Qasim Mirza ${ }^{6}$ \\ ${ }^{1}$ Department of Earth Sciences, Quaid-I-Azam University, Islamabad, Pakistan \\ ${ }^{2}$ Department of Metrology, COMSATS Institute of Information Technology (CIIT), Islamabad, Pakistan \\ ${ }^{3}$ Department of Geosciences, University of Oslo, Oslo, Norway \\ ${ }^{4}$ Oil and Gas Development Company Limited, Islamabad, Pakistan \\ ${ }^{5}$ Center of Pure and Applied Geology, University of Sindh, Jamshoro, Pakistan \\ ${ }^{6}$ Nespak, Pakistan \\ Email: shazia.asim1@gmail.com
}

Received 11 July 2014; revised 9 August 2014; accepted 2 September 2014

Copyright (C) 2014 by authors and Scientific Research Publishing Inc.

This work is licensed under the Creative Commons Attribution International License (CC BY).

http://creativecommons.org/licenses/by/4.0/

c) (7)

Open Access

\section{Abstract}

Publicly available seismic and well data are used to study the subsurface structure and stratigraphy of an area on the southern margin of the Central Indus Basin (CIB), Pakistan. Study area includes southern parts of the Punjab Platform and Sulaiman Foredeep tectonic units of the CIB. A regional scale East-West depth cross-section is prepared in South of hydrocarbon bearing Safed Koh Trend to Punjab Platform. It gives the structural configuration of various formations of Paleozoic-Cenozoic times. Reflectors are marked and correlated with the help of wells Drigri-01 and Bahawalpur East-01, located on seismic lines 914-RPR-03 and 916-YZM-05 respectively. These reflectors/formations are correlated with respect to ages to avoid the confusions as there are many truncations in the area. Average velocities are used for the depth computation. Depth cross-section (AB) shows that Punjab Monocline is a stable area with a shallow basement. In Punjab Platform all the formations dip gently to the West. Then they attain steep dips in the Sulaiman Foredeep/Depression area. Depth cross-section along the Drigri anticline which lies in the SE of Sakhi Sarwar anticline reveals that it is extended E-W over $17 \mathrm{~km}$ approx. and the reverse faults are present on both flanks of a fold, due to that a pop up structure is formed. It's a low amplitude fold, as it marks the southern end of Safed Koh Trend (first line of folding of the folded flank of Sub-Sulaiman Fore Deep). Subsurface structural variations at Bahawalpur show a buried high of Jurassic- 
Permian age. A sedimentary cover is $9 \mathrm{~km}$ thick in West and $3 \mathrm{~m}$ thick in East. Basement is uplifted at Bahawalpur High.

\section{Keywords}

\section{Seismic Interpretation, Central Indus Basin, Burried Ridge}

\section{Introduction}

The study area comprises of frontal fault propagation folded zone of Sulaiman Range, Sulaiman Depression and Punjab Monocline of Pakistan (Figure 1 \& Figure 2). It is bounded by longitude (70 06 "E - 72 16 "E) and latitude $\left(29^{\circ} 17^{\prime \prime N}-29^{\circ} 23^{\prime \prime N}\right)$. Seismic profiles from West to East are 914-RPR-03, 954-FZP-09, C95-LMT-05, W16-AT, B-01, PSPD-5085, PSPD-5340 and 916-YZM-05. A seismic line 914-RPR-03 lies in the NW of Rajanpur area of District D. G. Khan, with a Drigri-01 \& Kotrum-01 wells located at SP-270 and South of profile respectively. Drigri and Kotrum Anticlines mark the southern limit of the Safed Koh Trend. Bahawalpur East-01 well is located at SP-300 on seismic line 916-YZM-05. An East-West depth cross-section AB shows the

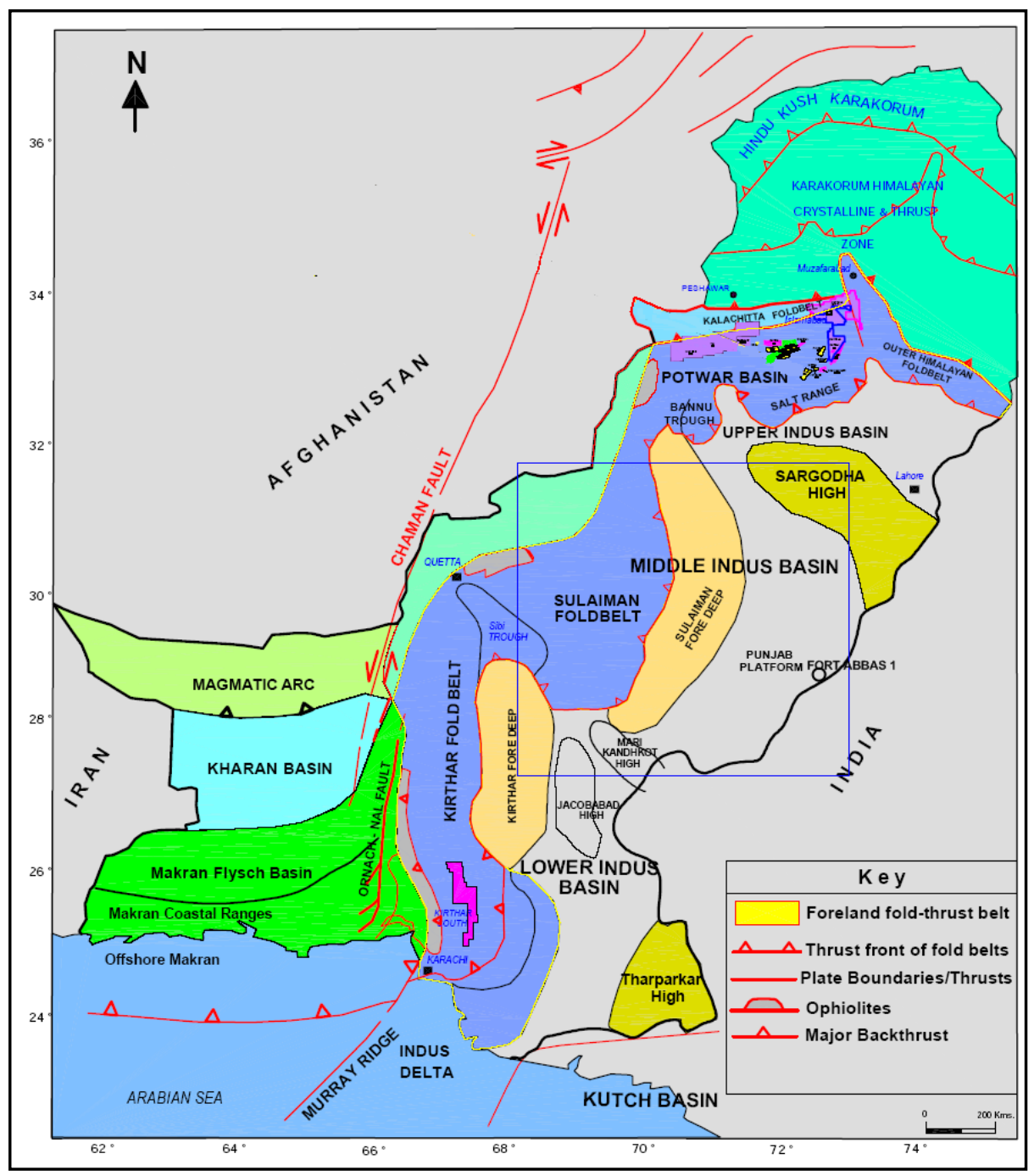

Figure 1. Research area lies in Punjab platform in middle Indus Basin [22]. 


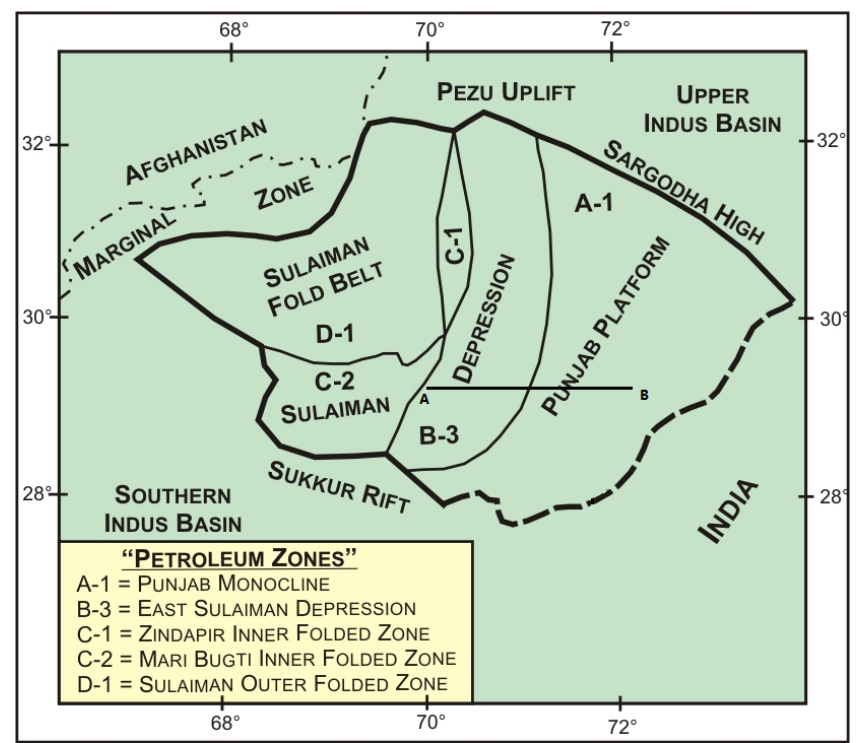

Figure 2. The profile covers the Punjab platform, Sulaiman Foredeep/Depression and edge of the frontal fault propagation fold zone (Main Thrust Front) [12].

structural and stratigraphical variations in the formations. The surface geology is made up of alluvium and loose material mainly brought by rivers and from desert in the East.

\section{Tectonic and Depositional Setting}

Tectonically Pakistan comprises of two domains of large landmasses, i.e. Tethyan and Gondwanian Domains and is continued by the Indo-Pakistan crustal plate. The northern most and western regions of Pakistan fall in Tethyan Domain, which have complicated geology and complex crustal structure, While the Indus Basin consists of the gondwanian domain [1]. The early rifting of micro-continents away from the northern margin of the Gondwanaland can be discussed with the development of Paleo-Neo-Tethys with a spreading ridge in between [2]. During Cretaceous, there was a period of tectonic instability. The spreading rate was high, $\sim 20-30 \mathrm{~cm} / \mathrm{a}$ in 80 - 53 Ma ([3]-[5]). There was a convergence between Indian and Eurasian plates in Tertiary time. To go with the prominent convergence and the late Paleocene collision between the Indian and the Eurasian plates in the North Pakistan, the area was also affected by the translation between Indian plate and Afghan Craton in the northwest [6] and by territory convergence between Arabian Plate and Afghan Craton ([7]-[11]) suggest that the oblique collision of the Eurasian and Indo-Pakistan plates caused the development of large scale; N-S running, left-lateral strike-slip faults in the basement which are responsible for the segmentation of the Indo-Pakistan Plate. Pakistan lies on the north western corner of the Indian Plate. The collision zone in the northern Pakistan has been subdivided as the Main Karakoram Thrust (MKT), Main Mantle Thrust (MMT), Main Boundary Thrust (MBT) and Salt Range Thrust (SRT) [12]. Pre-Cambrian Basement rocks are exposed along the Sargodha High. Lithospheric flexural buldge developed due to northward under thrusting of the Indian Plate and loading of South verging thrust sheets [13]. This was also suggested by [12], they explained the tectonic configuration of the Sargodha Ridge as an outer "swell” due to loading of Indian Shield by the Himalayan thrusts.

\section{Sedimentary Basins}

Two major sedimentary basins of Pakistan are Indus Basin and Baluchistan Basin. The Indus Basin is the largest basin in Pakistan, oriented in NE-SW direction including the 25,000 square kilometers of SE part of Pakistan. Tectonically Indus Basin is much stable area as compared to other tectonic zones of Pakistan [1]. The main feature which controlled the sedimentation in the proto-Indus Basin up to Jurassic was Precambrian Indian Shield whose topographic highs exist in the form of Kirana Hills (Sargodha High) and Nagar Parker. It is the Sargodha High which is considered to be a divide between Upper Indus Basin and Lower Indus Basin. 
The classification of Indus Basin:

Upper Indus Basin: Kohat Sub-basin \& Potwar Sub-basin;

Lower Indus Basin: Central Indus Basin \& southern Indus Basin (Figure 1).

Another major feature of basement topography is Khair-pur-Jacobabad High and its associated structures which grew through Jurassic and Cretaceous/Paleocene ages and divided the Lower Indus Basin further into two basins namely southern and Central Indus Basin [14]. Punjab Platform is an eastern part of Middle Indus Basin in Pakistan with Sulaiman depression and fold belt in the West, Sargodha High in North and Pokhran High in the South [15]. Jacobabad and Mari Kandhkot highs are together termed as the Sukkur Rift. Central Indus Basin is also named as Sulaiman Sub-basin [16]. It is sub divided into (Figure 2):

Punjab Platform;

Sulaiman Sub-basin;

Sulaiman Depression;

East Sulaiman Depression;

Zindapir Inner Folded Zone;

Mari Bugti Inner Folded Zone;

Sulaiman Fold Belt;

Punjab Platform:

This unit marks the eastern segment of Central Indus Basin. Tectonically it is a broad monoclinic dipping gently towards the Sulaiman depression. Punjab Platform is tectonically the least affected area because of its greater distance from collision zone.

Sulaiman Depression:

This depression is a longitudinally oriented area of subsidence, it becomes arcuate and takes up a transverse orientation along its southern rim. The Sulaiman Foredeep/Depression is a broad syncline with a very gentle, undisturbed eastern limb \& steeper western limb. The eastern limb has monoclinal dips \& over $200 \mathrm{~km}$ wide. The western flank of the depression includes Zindapir Inner Folded Zone while Murri Bugti Inner Folded Zone lies in the South, to the East it merges in Punjab platform. The depth of the basement beneath this syncline is about $8 \mathrm{~km}$.

Sulaiman Fold Belt:

This is a major tectonic feature in the proximity of collision zone and therefore contains a large number of disturbed anticlinal features. The trends of the structure are mainly East-West.

General stratigraphy of Central Indus Basin is given in Table 1.

\section{Previous Work Done}

Previous work was done in the North of Drigri-Anticline in East-West direction, along Sakhi-Sarwar [17], along Zindapir Anticlinonrium ([18] [19]) and generalized cross section across the Middle Indus Basin ([14] [20]) were made.

\section{Petroleum Potential}

\section{Source Rocks}

Shales of Shinawari Formation and Chichali formation of Mesozoic act as a source in the Punjab Platform and

Sulaiman Depression. These source rocks have acquired sufficient maturity to generate large volumes of gas.

Reservoir Rocks

Proven Reservoir Rocks of the Mesozoic age are Lumshiwal, Samanasuk, Shinawari and Datta formations of Punjab Platform area with discoveries at Tal, Chanda, Dhulian, Panjpir, Nandpur, toot and Meyal fields.

\section{Sealing Mechanism}

Drigri and Kotrum structures are gentle anticlines and the seal is provided by Ranikot shales (Paleocene) on Late Cretaceous Pab Sandstones.

\section{Work Flow}

All of the previous work done by respectable authors has been very helpful in the East-West correlation of the seismic profiles. The boundaries are determined by Drigri-01 well in West and Bahawalpur-01 well in East. The 
Table 1. Stratigraphy of central Indus Basin (Kadri, 1995).

\section{STRATIGRAPHY OF PAKISTAN}

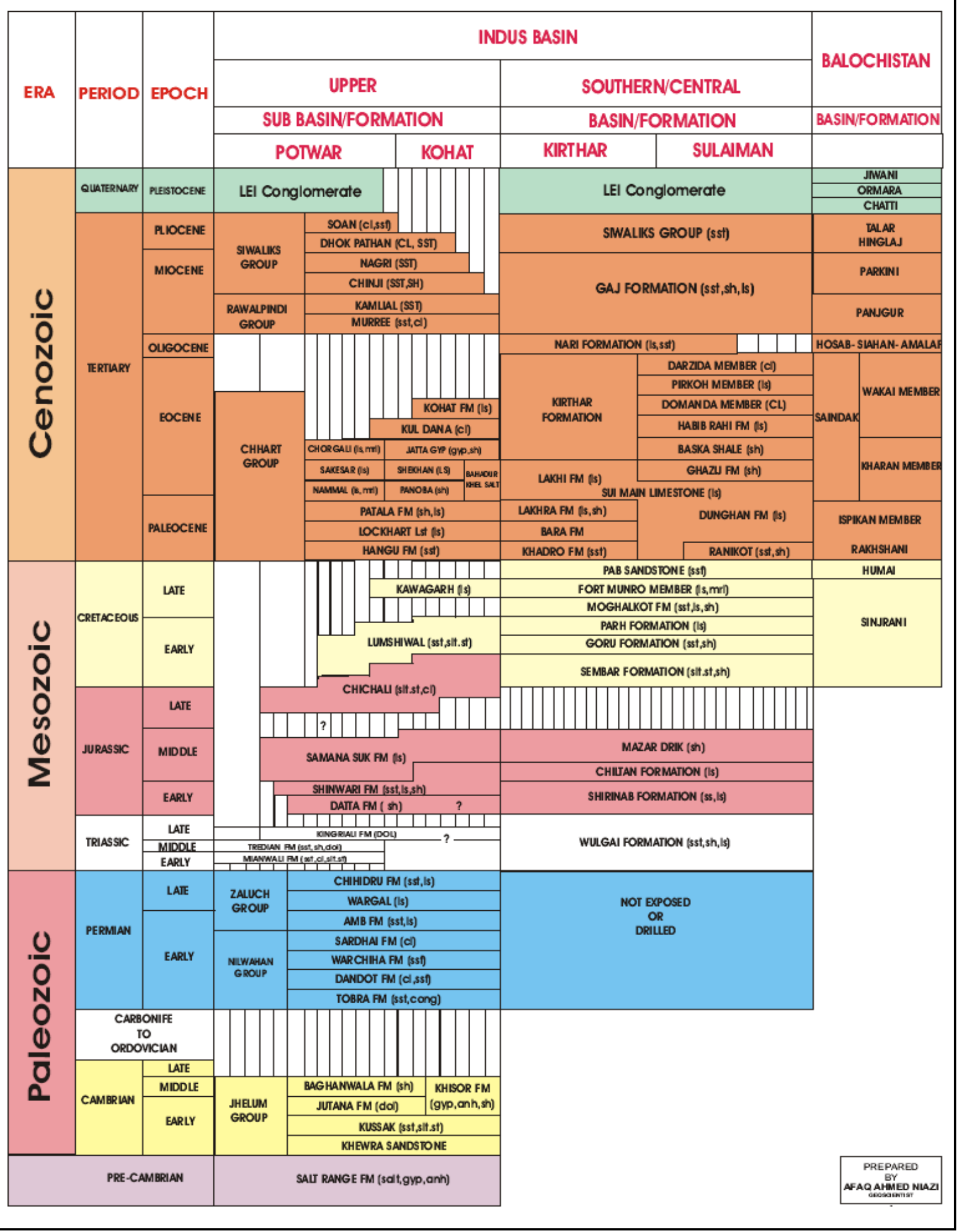


area in between is correlated by seismic lines keeping in view the previously made cross sections.

On the basis of previous work, Well and Seismic data the few shortcomings are fulfilled as either Paleozoic in the area was not correlated before or Pre-Cambrian, Paleozoic, Mesozoic (cretaceous, Jurassic, Triassic) were not discussed separately. Also depths were not mentioned in some cases and early cross sections were made in Time domain because depth conversion is very sensitive to the velocities used.

Reflection seismology is a remote imaging method used in petroleum exploration [21].

Seismic lines used in this study are 914-RPR-03, 954-FZP-09, C95-LMT-05, W16-AT, B-01, PSPD-5085, PSPD-5340 and 916-YZM-05. Reflectors are picked by matching seismic with synthetic (Figure 3 \& Figure 4) and using well tops (Table $2 \&$ Table 3 ) for the part where logs are not run or absent. Correlation of reflectors

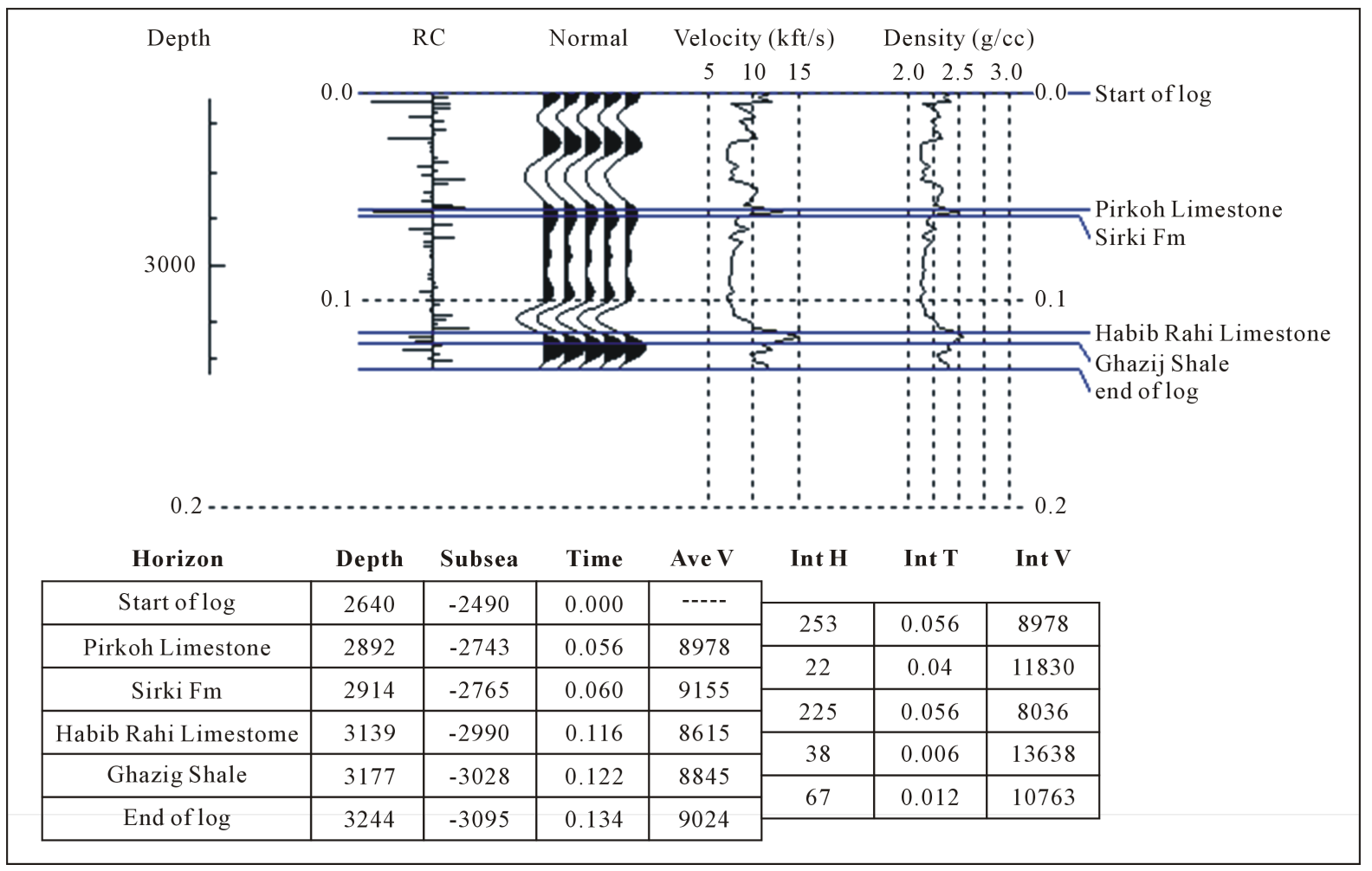

Figure 3. Generation of synthetic seismogram at well Drigri-01.

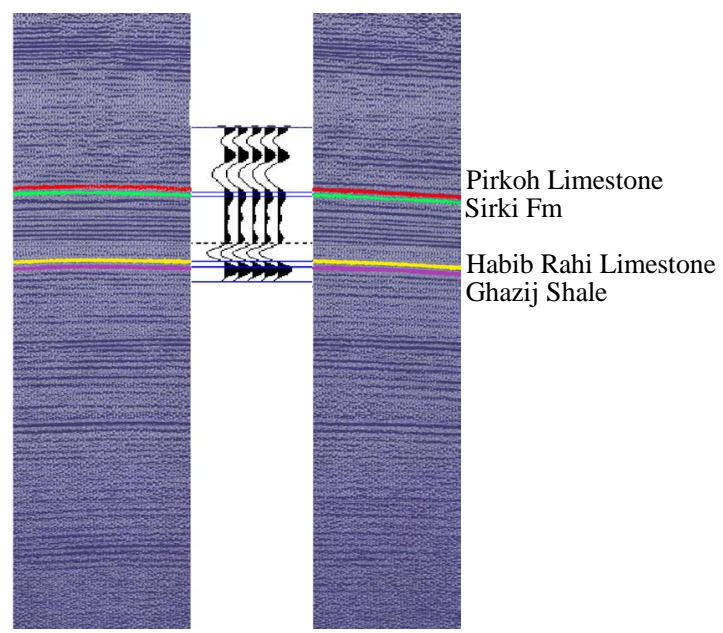

Figure 4. Matching of synthetic traces with seismic line 914-RPR-03. 
Table 2. Well tops of Drigri-01 which lies in West of depth cross-section AB.

\begin{tabular}{cccccc}
\hline Well name & Drigri-01 & Type & EX & Status & ABD \\
\hline Operator & OGDC & Spud date & $02 / 09 / 1992$ & Compl. date & $28 / 11 / 1992$ \\
Depth $(\mathrm{m})$ & 3250.0 & Latitude & 292204.92 & Longitude & 701054.28 \\
K.B.E & 149.02 & Province & PUNJAB & Formation & GHAZIJ \\
\hline Sr. no & Formation age & Formation & Top (m) & Thickness (m) \\
\hline 1 & PLIOCENE & DHOK PATHAN & 0.0 & 847.0 \\
2 & PLIOCENE & NAGRI & 847.0 & 1011.0 \\
3 & MIOCENE & CHINJI & 1858.0 & 406.0 \\
4 & OLIGOCENE-MIOCENE & GAJ-NARI & 2264.0 & 326.0 \\
5 & EOCENE & DRAZINDA & 2590.0 & 302.0 \\
7 & EOCENE & PIRKOH & 2892.0 & 22.0 \\
9 & EOCENE & SIRKI & 2914.0 & 225.0 \\
\hline
\end{tabular}

Table 3. Well tops of Bahawalpur-01 which lies in East of depth cross-section AB.

\begin{tabular}{|c|c|c|c|c|c|}
\hline Well name & Bahawalpur East-01 & Type & $\mathrm{EX}$ & Status & $\mathrm{ABD}$ \\
\hline Operator & SHELL & Spud date & 19/12/1980 & Compl. date & $17 / 02 / 1981$ \\
\hline Depth (m) & 3024.0 & Latitud & 292207.00 & Longitude & 720907.40 \\
\hline K.B.E & 134.90 & Province & PUNJAB & Formation & BASEMENT \\
\hline Sr. no & Formation age & \multicolumn{2}{|c|}{ Formation } & Top (m) & Thickness (m) \\
\hline 1 & MIOCENE-QUATENARY & \multicolumn{2}{|c|}{ SIWALIK RAWALPINDI } & 0.0 & 800.00 \\
\hline 2 & EOCENE & \multicolumn{2}{|c|}{ CHORGALI } & 800.00 & 121.0 \\
\hline 3 & EOCENE & \multicolumn{2}{|c|}{ SAKESAR } & 921.0 & 72.0 \\
\hline 4 & PALEOCENEEOCENE & \multicolumn{2}{|c|}{ NAMMAL } & 993.0 & 64.0 \\
\hline 5 & EOCENE & \multicolumn{2}{|c|}{ GHAZIJ SUI MEMBER } & 1057.0 & 17.0 \\
\hline 6 & PALEOCENE & \multicolumn{2}{|c|}{ DUNGHAN } & 1074.0 & 5.0 \\
\hline 7 & EARLY CRETACEOUS & \multicolumn{2}{|c|}{ CHICHALI } & 1079.0 & 15.0 \\
\hline 8 & MIDDLE JURASSIC & \multicolumn{2}{|c|}{ SAMANA SUK } & 1094.0 & 98.0 \\
\hline 9 & MIDDLE JURASSIC & \multicolumn{2}{|c|}{ SHINWARI } & 1192.0 & 95.0 \\
\hline 10 & EARLY JURASSIC & \multicolumn{2}{|c|}{ DATTA } & 1287.0 & 13.0 \\
\hline 11 & MIDDLE TRIASSIC & \multicolumn{2}{|c|}{ TREDIAN } & 1300.0 & 94.0 \\
\hline 12 & EARLY PERMIAN & \multicolumn{2}{|c|}{$\mathrm{AMB}$} & 1394.0 & 71.0 \\
\hline 13 & EARLY PERMIAN & \multicolumn{2}{|c|}{ SARDHAI } & 1465.0 & 98.0 \\
\hline 14 & EARLY PERMIAN & \multicolumn{2}{|c|}{ WARCHA } & 1563.0 & 122.0 \\
\hline 15 & EARLY PERMIAN & \multicolumn{2}{|c|}{ DANDOT } & 1185.00 & 45.0 \\
\hline 16 & EARLY PERMIAN & \multicolumn{2}{|c|}{ TOBRA } & 1730.0 & 10.0 \\
\hline 17 & MIDDLE CAMBRIAN & \multicolumn{2}{|c|}{ KUSSAK } & 1740.0 & 129.0 \\
\hline 18 & EARLY CAMBRIAN & \multicolumn{2}{|c|}{ KHEWRA SANDSTONE } & 1869.0 & 285.0 \\
\hline 19 & Pre-Cambrian & \multicolumn{2}{|c|}{ SALT RANGE } & 2154.00 & 817.0 \\
\hline 20 & PRE CAMBRIAN & \multicolumn{2}{|c|}{ BASEMENT } & 2971.0 & 53.0 \\
\hline
\end{tabular}


in rest of the seismic lines keeping in mind for the different surveys' parameters, datum planes and jump correlation. Then next stage is solving average velocities given at each seismic section in order to encounter lateral changes in velocities (Figure 5). After that a Depth computation by multiplication of average velocities with one way time of reflectors. The depth cross-sections are plotted side by side to get a profile AB (Figure 6).

\section{Results and Discussion}

From the representative Depth cross-section (Figure 6) prepared with the help of Seismic profiles, it is seen that all the formations dip gently to the West. They dip more steeply in the Sulaiman Foredeep. In the East, formations are successively truncated at the Base Tertiary. These stratigraphic traps give a good possibility of hydrocarbon presence provided by a fact if adequate seal is present.

There is a Thrust fault along Drigri that cuts in the Paleocene \& Mesozoic sediments with a vertical throw of

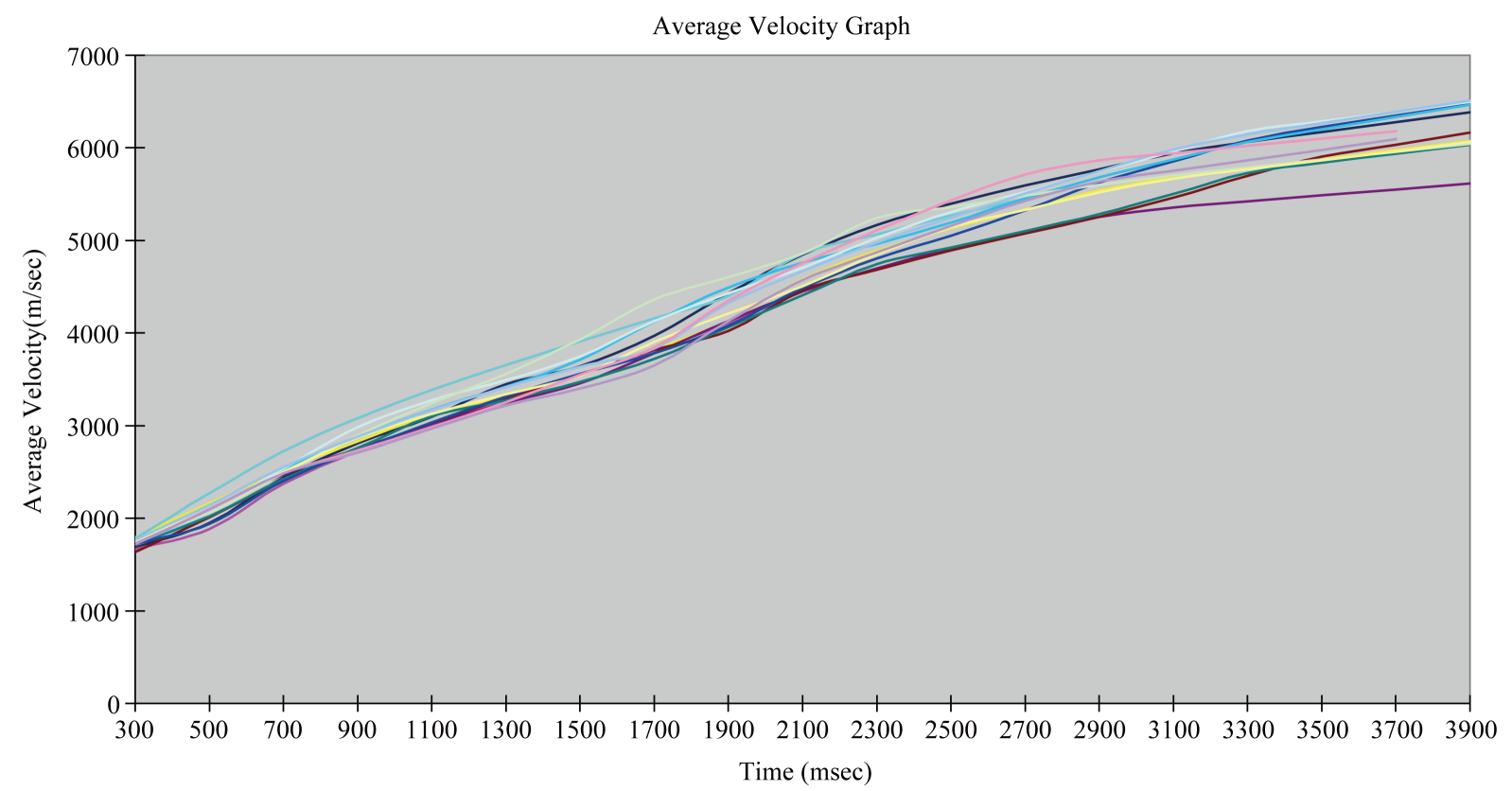

Figure 5. Average velocities are used for depth computation.

Correlation of the Seismic lines from Behawalpur East-01 to Drigri-01

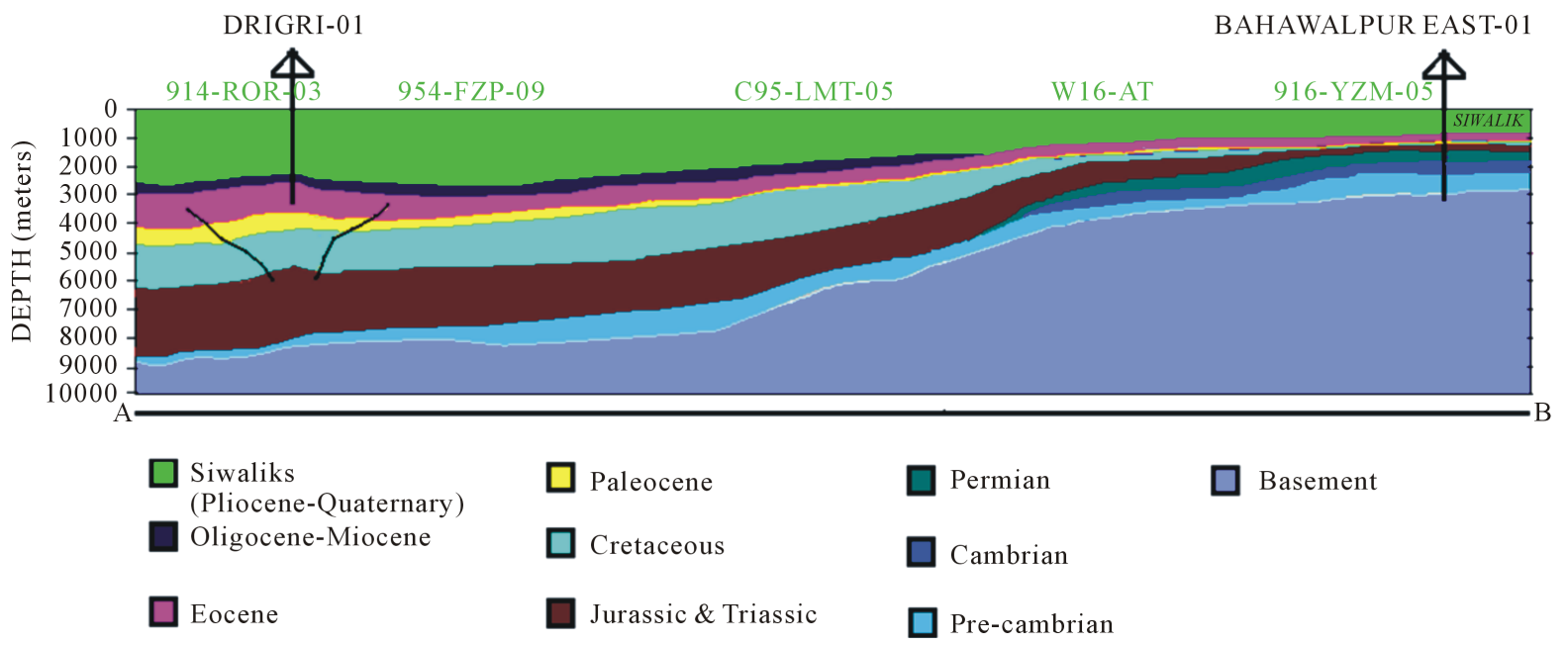

Figure 6. Depth cross-section AB in East-West direction. 
about 10 msec. This anticline may have been formed at the expense of flow of Eocene shales. Also the flow of shales of Mesozoic age is very prominent in Drigri anticline. The fault propagation \& fault bend folds are the most important structural features \& they form important traps for hydrocarbon in the foreland fold \& thrust belts. The frontal Sulaiman \& Khirthar ranges are the most prospective \& productive line of folding as compared to middle Indus. The Sakhi Sarwar structure in the Eastern Sulaiman range is a fault propagation fold. The Domanda, Dhodhak, Rodho, Zindapir, Fort Munro, Pirkoh, Loti, Uch \& Mazarane structures in the sulaiman \& Khirthar Ranges are thrusted anticlines ([19]).

Nagri \& Chinji Formation almost $1700 \mathrm{~m}$ thick have been deposited in Drigri anticline. Siwaliks are $800 \mathrm{~m}$ thick in East. Nari Formation (Oligocene) is overlain by Gaj Formation in Drigri anticline which onlaps (unconformable) on Eocene strata in East. Nari Formation truncates in East. Eocene, Paleocene \& Cretaceous are 1300 m, $800 \mathrm{~m} \& 150 \mathrm{~m}$ approx. thick respectively in West. Eocene strata thins out in East but still attain a thickness of more than $250 \mathrm{~m}$ in East suggesting the presence of more accommodation space for its sedimentation in West. The oldest rocks encountered in Punjab Platform through drilling are of Infracambrian Salt Range Formation. Pre-Himalayan orogenic movements have resulted in prolonged uplifts/sea regression causing unconformities. As a result, several salt cored anticline structures are expected in the southern portion of this monocline ([14] [19]). Paleocene \& Cretaceous strata diminishes and onlap on Jurassic sediments in East. This suggests that Base Cretaceous is an unconformable surface and the basement uplift has occurred before Cretaceous. In the subsurface, Punjab Platform contains marine Paleozoic, Mesozoic and Neogene sediments. The zone is characterized by regional unconformities [16]. A series of small highs are present from North to South as Budhuana, Panjpir, Sarai Sidhu, Nandpur, Tola, Karampur, Bahawalpur East and Marot.

\section{Conclusion}

The depth cross section AB shows the high in subsurface formations at well Bahawalpur East-01 location. East Jurassic and Triassic sediments show their presence. Jurrasic and Triassic are $300 \mathrm{~m}$ in East and thicken in West and achieve the thicknesses greater than $1000 \mathrm{~m}$ along Drigri and Kotrum anticlines. Whereas Permian, Cambrian and Pre-Cambrian formations which are correlated from Bahawalpur East-01 well, show a thick sedimentation in East as Permian is $346 \mathrm{~m}$, Cambrian is $414 \mathrm{~m}$ and Pre-Cambrian (Salt Range Formation) is $817 \mathrm{~m}$ thick. Pre-Cambrian \& Paleozoic sediments may present below a thick pile of Mesozoic sediments in West, but they are not drilled due to greater depths. Basement is uplifted in the East. It is gradually dipping westward and it is more than $9 \mathrm{~km}$ deep beneath the deformation front in the eastern Sulaiman range.

\section{Acknowledgements}

Authors are thankful to Landmark Resources (LMKR) and Directorate General Petroleum Concessions (DGPC) for providing seismic data of the area.

\section{References}

[1] Kazmi, A.H. and Jan, M.Q. (1997) Geology \& Tectonics of Pakistan. Graphic Pub., 650 p.

[2] Stocklin, J. (1977) Structural Correlation of the Alpine Ranges between Iran and Central Asia. Société géologique de France, Paris, Mémoire Hors Série, 333-353.

[3] Gnos, E., Immenhauser, A. and Peters, T. (1997) Late Cretaceous/Early Tertiary Convergence between Indian and Arabian Plates Recorded in Ophiolites and Related Sediments. Tectonophysics, 271, 1-19. http://dx.doi.org/10.1016/S0040-1951(96)00249-1

[4] Mahoney, J.J. (1988) Deccan Traps. In: Macdougall, J.D., Ed., Continental Flood Basalts, Kluwer Acd. Pub., Holland, 151-194.

[5] Farah, A., Lawrence, R.D. and De, J. (1984) An Overview of the Tectonics of Pakistan. In: Haq, B.U. and Milliman, J.D., Eds., Marine Geology and Oceanography of Arabian Sea and Coastal Pakistan, Van No Strand and Reinhold Co. and Scin. and Academic Editions, New York, 161-176.

[6] Banks, B.P. and Warburton, J. (1986) Passive-Roof, Duplex Geometry in the Frontal Structures of the Kirthar and Suleiman Belts, Pakistan. Journal of Structural Geology, 8, 229-237. http://dx.doi.org/10.1016/0191-8141(86)90045-3

[7] Zaigham, N.A. and Mallick, K.A. (2000) Prospect of Hydrocarbon Associated with Fossil-Rift Structures of the Southern Indus Basin, Pakistan. American Association of Petroleum Geologist AAPG Bulletin, 84, 1833-1848. 
[8] Bannert, D., Cheema, A. and Ahmed, A. (1989) Interpretation of LANDSAT-MSS Imagery of the Sulaiman and Kirthar Ranges in Western Pakistan. HDIP-BGR Internal Report No. 83.2068.1.

[9] Bannert and Raza, H.A. (1992) The Segmentation of the Indo-Pakistan Plate. Pakistan Journal of Hydro Research, 4, 4-18.

[10] Bannert, I. and Helmcke, D. (1995) Surface and Subsurface Evidence for the Existence of the Sualiman Basement Fault of the North Western Indian Plate in Pakistan. Abstract of the Second South Asia Geological Congress, Colombo, $21 \mathrm{p}$.

[11] Bender, F.K. and Raza, H.A. (1995) Geology of Pakistan. Borntraeger, Berlin, Stuttgart.

[12] Yeats, R.S. and Lawrence, R.D. (1984) Tectonics of the Himalayan Thrust Belt in Northern Pakistan. In: Haq, B.U. and Milliman, J.D., Eds., Marine Geology and Oceanography of the Arabian Sea and Coastal Pakistan, Van Nostrand Reinhold, New York, 117-198.

[13] Duroy, Y., Farah, A. and Lillie, R.J. (1989) Surface Densities and Lithospheric Flexure of the Himalayan Foreland in Pakistan. Tectonics of the Western Himalayas. Geological Society of America, Special Paper 232, Boulder, 217-236.

[14] Kadri, I.B. (1995) Petroleum Geology of Pakistan. Pakistan Petroleum Limited, Ferozsons (pvt) Limited, 275 p.

[15] Aadil, N. and Sohail, G.M. (2011) Stratigraphic Correlation and Isopach Maps of Punjab Platform in Middle Indus Basin, Pakistan. AAPG, Search and Discovery Article-10364, Tulsa.

[16] Raza, H.A., Ahmed, R., Ali, S.M. and Ahmad, J. (1989) Petroleum Prospects Sulaiman Sub Basin, Pakistan. Pakistan Journal of Hydrocarbon Research, 1, 21-56.

[17] Porth, H. and Raza, H.A. (1990) On the Geology and Hydrocarbon Prospects of Sulaiman Province, Indus Basin, Pakistan. Hydrocarbon Development Institute of Pakistan/Federal Institute of Geoscience and Natural Resources, Unpublished Report, 127 p.

[18] Kemal, A., Balkwill, H.R. and Stoakes, F.A. (1991) Indus Basin Hydrocarbons Plays. International Petroleum Seminar on New Directions and Strategies for Accelerating Petroleum Exploration and Production in Pakistan, 16-57.

[19] Humayun, M., Lillie, R.J. and Lawrence, R.D. (1991) Structural Interpretation of the Eastern Sulaiman Foldbelt and Foredeep, Pakistan. Tectonics, 10, 299-324. http://dx.doi.org/10.1029/90TC02133

[20] Quadri, V. and Shuaib, S.M. (1986) Hydrocarbon Prospects of southern Indus Basin, Pakistan. AAPG Bulletin, 70, 730-747.

[21] Robinson, E.A. and Treitel, S. (2008) Digital Imaging and Deconvolution: The ABCs of Seismic Exploration and Processing. SEG, Tulsa, 424 p. http://dx.doi.org/10.1190/1.9781560801610

[22] Kazmi, A.H. and Snee, M.Q. (1989) Geology \& Tectonics of Pakistan. 4-11. 
Scientific Research Publishing (SCIRP) is one of the largest Open Access journal publishers. It is currently publishing more than 200 open access, online, peer-reviewed journals covering a wide range of academic disciplines. SCIRP serves the worldwide academic communities and contributes to the progress and application of science with its publication.

Other selected journals from SCIRP are listed as below. Submit your manuscript to us via either submit@scirp.org or Online Submission Portal.
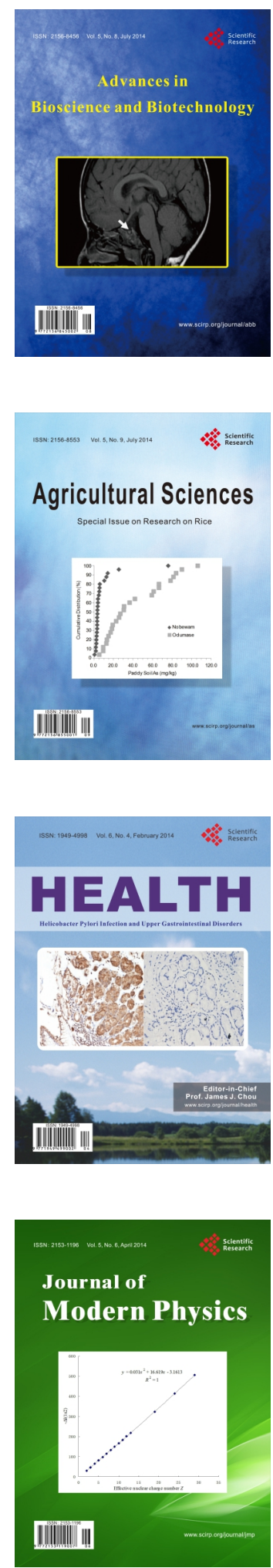
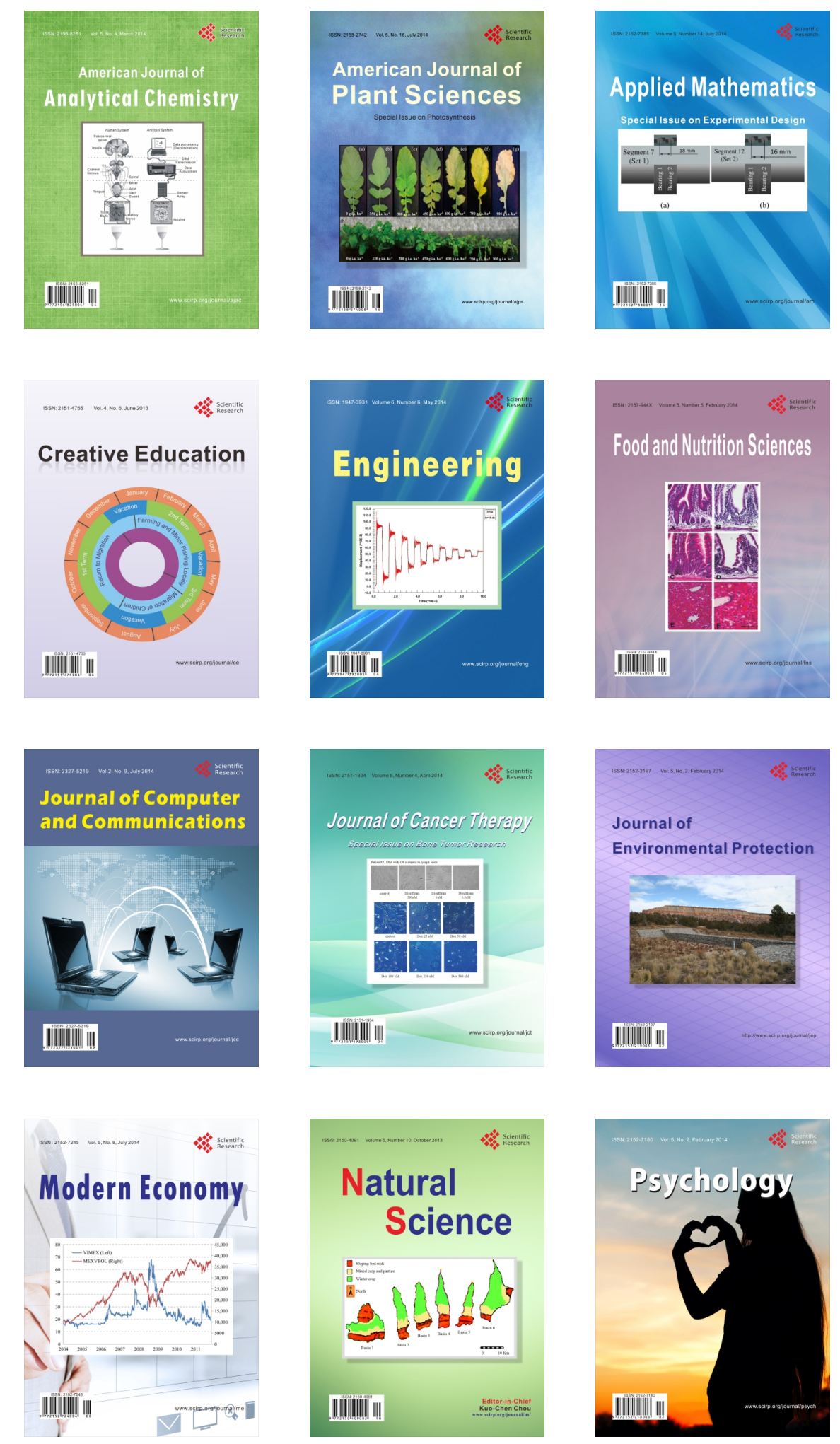